\title{
Simulasi Difraksi Fraunhofer Menggunakan Media Spreadsheet dan GNU Octave Sebagai Alternatif Pembelajaran dimasa Pandemi
}

\author{
${ }^{1,3}$ Aditya Yoga Purnama, ${ }^{2}$ Heru Kuswanto, ${ }^{1}$ Syella Ayunisa Rani, ${ }^{1}$ Himawan Putranta, \\ ${ }^{3}$ Puji Hariati Winingsih \\ ${ }^{1}$ Education Science Department, Concentration of Physics Education, Graduate School, \\ Universitas Negeri Yogyakarta, Jl. Colombo No. 1, Sleman, Yogyakarta, 55281, Indonesia \\ ${ }^{2}$ Faculty of Sciences Education, Universitas Negeri Yogyakarta, Jl. Colombo No. 1, Sleman, \\ Yogyakarta, 55281, Indonesia Pendidikan \\ ${ }^{3}$ Department of Physics Education, Universitas Sarjanawiyata Tamansiswa, Jalan Batikan \\ UH.III/1043, Yogyakarta 55167, Indonesia \\ Email Korespondensi: adityayoga@ustjogja.ac.id
}

\begin{tabular}{|c|c|}
\hline Article Info & bstract \\
\hline $\begin{array}{l}\text { Article History } \\
\text { Received: } 22 \text { June } 2021 \\
\text { Revised: 02 August } 2021 \\
\text { Published: } 30 \text { Dec } 2021\end{array}$ & \multirow{2}{*}{$\begin{array}{l}\text { The title of this paper is Fraunhofer diffraction simulation using spreadsheet } \\
\text { and GNU octave media as an alternative for learning during the pandemic. } \\
\text { This paper aims to present an alternative to distance learning during the } \\
\text { COVID-19 pandemic by using simulations using spreadsheets and GNU } \\
\text { Octave media. Optical practicum in physics laboratories can not be done } \\
\text { during pandemics. So the solution that can be offered is to use simulations on } \\
\text { optical subjects of diffraction material. In the simulation making activities } \\
\text { students can learn and explore about the phenomenon of diffraction. } \\
\text { Simulations using the equations used in the research of Zhang et al. in } 2013 . \\
\text { This simulation is used to visualize the effect of variations in different } \\
\text { parameters such as wavelengths and gap widths in Fraunhofer diffraction } \\
\text { patterns. This paper has successfully simulated Fraunhofer's diffraction using } \\
\text { spreadsheets as well as GNU Octave. This distance learning allows students to } \\
\text { develop fraunhofer computational computational skills and conceptual } \\
\text { understanding of diffraction }\end{array}$} \\
\hline $\begin{array}{l}\text { Keywor } \\
\text { Fraunh } \\
\text { Spreads } \\
\text { Octave }\end{array}$ & \\
\hline Info & bst \\
\hline $\begin{array}{l}\text { Sejarah Artikel } \\
\text { Diterima: 22 Juni } 2021 \\
\text { Direvisi: 02 Agustus } 2021 \\
\text { Dipublikasi: } 30 \text { Des } 2021\end{array}$ & \multirow{2}{*}{$\begin{array}{l}\text { Paper ini memiliki tujuan untuk menyajikan alternatif pembelajaran jarak jauh } \\
\text { dimasa pandemi COVID-19 yaitu dengan menggunakan simulasi menggunakan } \\
\text { media spreadsheet dan GNU Octave. Praktikum Optik di laboratorium fisika } \\
\text { tidak bisa dilakukan dimasa pandemi. Sehingga solusi yang dapat ditawarkan } \\
\text { adalah menggunakan simulasi pada mata kuliah optik materi difraksi. Pada } \\
\text { kegiatan pembuatan simulasi mahasiswa dapat mempelajari dan bereksplorasi } \\
\text { mengenai fenomena difraksi. Simulasi menggunakan persamaan yang } \\
\text { digunakan dalam penelitian Zhang et al. pada tahun 2013. Simulasi ini } \\
\text { digunakan untuk memvisualisasikan efek variasi parameter yang berbeda } \\
\text { seperti panjang gelombang dan lebar celah pada pola difraksi Fraunhofer. Paper } \\
\text { ini telah berhasil membuat simulasi difraksi Fraunhofer menggunakan } \\
\text { spreadsheet maupun GNU Octave. Pembelajaran jarak jauh ini memungkinkan } \\
\text { mahasiswa untuk mengembangkan keterampilan komputasi dan pemahaman } \\
\text { konseptual difraksi Fraunhofer. }\end{array}$} \\
\hline $\begin{array}{l}\text { Difraksi Fraunhofer, } \\
\text { Spreadsheet, GNU Octave }\end{array}$ & \\
\hline
\end{tabular}

Sitasi:. Purnama, A.Y., Kuswanto, N., Rani, S.A., Putranta, H., \& Hariati, P. (2021), Simulasi Difraksi Fraunhofer Menggunakan Media Spreadsheet dan GNU Octave Sebagai Alternatif Pembelajaran dimasa Pandemi, Kappa Journal. 5(2), 158-165 


\section{PENDAHULUAN}

Optik merupakan salah satu cabang fisika yang mempelajari sifat cahaya. Banyak kesulitan dalam mempelajari materi optik terutama materi optik geometri (Pradana et al., 2017). Materi optik yang dikaji dalam artikel ini adalah difraksi. Materi difraksi ini masalah yang cukup rumit karena memerlukan praktik laboratorium (Yanuarief, 2016). Untuk memecahkan masalah tersebut dilakukan percobaan atau penelitian di laboratorium fisika, namun saat pandemi COVID-19 kegiatan tersebut tidak dapat dilakukan. Masalah fisika yang semula sangat sulit dan rumit untuk diselesaikan sekarang bertambah lagi dengan adanya pandemi ini. Solusi yang dapat ditawarkan adalah pembelajaran dari rumah menggunakan simulasi komputer menggunakan Spreadsheet dan Octave.

Spreadsheet memiliki potensi yang dalam pembelajaran fisika seperti kemampuan visualisasi yang dinamis pada suatu gejala fisika (Nurdianto et al., 2020). Keunggulan pemodelan menggunakan spreadsheet telah diakui secara luas. Fitur seperti entri data, manipulasi data, dan grafik menjadikan spreadsheet salah satu program penting dalam menangani data (Valenko \& Klanšek, 2017). Spreadsheet telah banyak digunakan terutama dalam materi optik untuk memvisualisasikan distribusi intensitas cahaya pada fiber optik (Pratidhina et al., 2020). Visualisasi tersebut dapat membantu mahasiswa dalam memahami persamaan matematis dan mengetahui hubungan teori dan eksperimen. Hal ini menunjukkan bahwa spreadsheet menjadi alat pedagogis yang penting dalam pemecahan masalah fisika. Sedangkan GNU Octave merupakan software gratis yang digunakan untuk memvisualisasikan data. Octave merupakan tiruan dari Matlab yang tersedia untuk berbagai sistem operasi seperti Windows dan Mac OS. Penggunaan software Octave sudah pernah dilakukan dalam menganalisis gerakan komponen pada Monobike. Hasil analisis pada Monobike tersebut secara teoritis dan simulasi adalah sama, sehingga dapat dikatakan penelitian tersebut akurat (Herraprastanti \& Jatmiko, 2019). Selain itu penggunaan simulasi dengan media PhET juga sudah dilakukan oleh peneliti sebelumnya dengan tujuan untuk mendeskripsikan peningkatan kemampuan menganalisis siswa. Hasil dari penelitian tersebut menunjukkan simulasi PhET mampu meningkatkan kemampuan menganalisis dalam pembelajaran fisika (Hati \& Sapiruddin, 2020).

Berdasarkan beberapa penelitian terdahulu mengenai manfaat Spreadsheet dan Octave, maka artikel ini melakukan penelitian fenomena difraksi Fraunhofer menggunakan Spreadsheet dan Octave. Selain itu, simulasi menggunakan Spreadsheet dan Octave belum pernah dilakukan oleh peneliti sebelumnya sehingga ini merupakan kebaharuan dalam pembelajaran fisika terutama materi optik.

\section{METODE}

Simulasi difraksi Fraunhofer pada penelitian ini menggunakan spreadsheet dan GNU Octave. Pembuatan simulasi menggunakan persamaan yang didasarkan dari penelitian sebelumnya oleh (Zhang et al., 2013). Simulasi ini digunakan untuk memvisualisasikan efek variasi parameter yang berbeda seperti Panjang gelombang dan lebar celah pada pola difraksi Fraunhofer. Skema difraksi Fraunhofer satu bukaan lingkaran ditunjukkan pada Gambar 1.

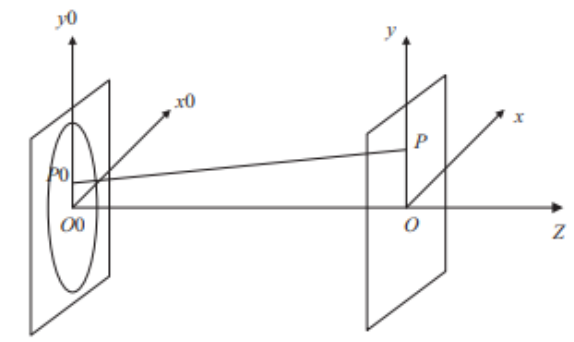

Gambar 1. Skema Difraksi Fraunhofer dari one circular aperture 
Intensitas cahaya titik $\mathrm{P}(\mathrm{x}, \mathrm{y})$ dari pola difraksi dapat menggunakan persamaan (1). Visualisasi difraksi Fraunhofer satu bukaan lingkaran dibuat dalam grafik dua dimensi menggunakan persamaan 1. Visualisasi menggunakan GNU Octave digunakan pada persamaan 2 yang mengubah satu bukaan persegi menjadi satu bukaan sejajar.

$$
\begin{aligned}
& I(r)=\left(\frac{k a^{2}}{2 z}\right)^{2}\left[\frac{2 J_{1}(k a r / z)}{k a r / z}\right]^{2} \\
& I=I_{0}\left[\frac{\sin \frac{\pi x a}{\lambda f}}{\frac{\pi x a}{\lambda f}}\right]^{2}
\end{aligned}
$$

Dimana, $a$ adalah radius dari bukaan melingkar, dan $J_{1}(x)$ adalah Fungsi Bessel orde pertama, dan $z$ adalah panjang fokus lensa. Tampilan spreadsheet ditunjukkan pada Gambar 2.

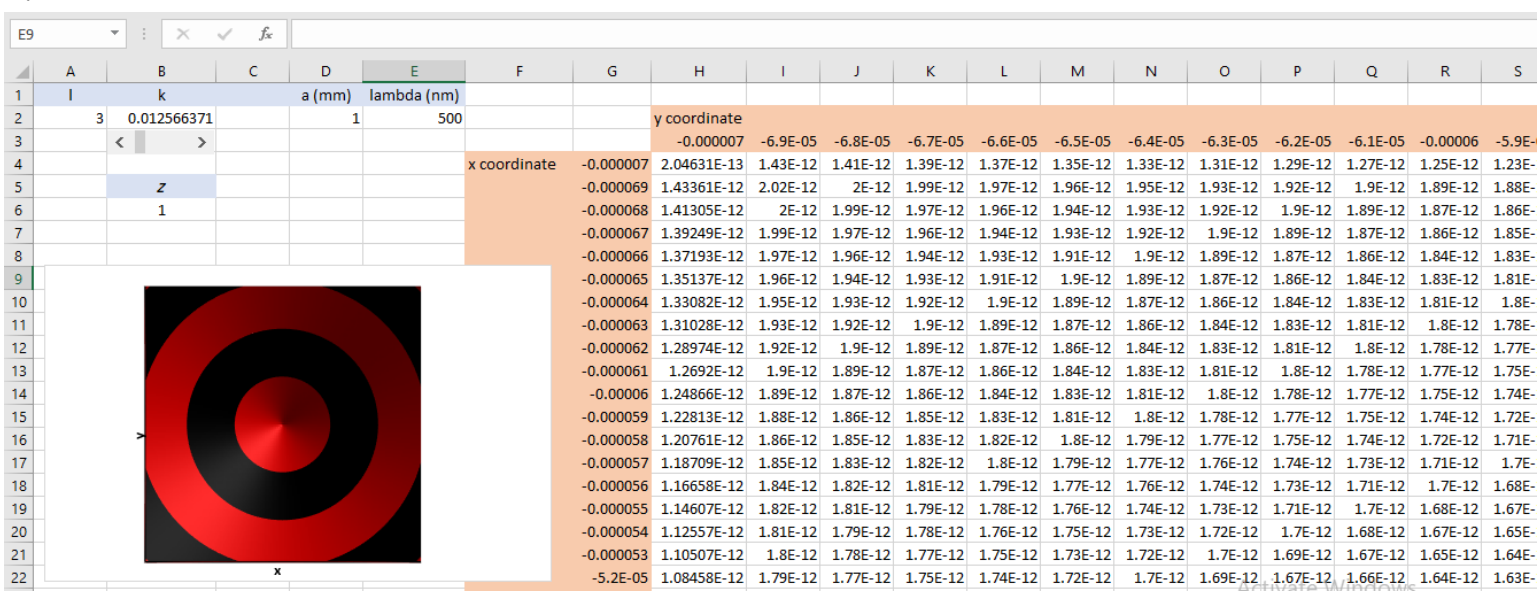

Gambar 2. Screenshot spreadsheet untuk memvisualisasikan difraksi Fraunhofer.

Tabel 1. Formula yang digunakan dalam spreadsheet

\begin{tabular}{ccl}
\hline Cell & Variabel & \multicolumn{1}{c}{ Formula } \\
\hline A2 & Orde Fungsi Bessel & $=3$ \\
B2 & Bilangan gelombang & $=2 * \mathrm{PI}() / \mathrm{E} 2$ \\
D2 & Lebar celah & $=1$ \\
E2 & Panjang gelombang & $=$ interval 400 sampai 800 \\
B6 & Panjang fokus lensa & $=1$ \\
G4-G144 & X-koordinat & $=$ Range $(-0.000007: 0.000007)$, interval 0,1 \\
H3-ER3 & y-koordinat & $=$ Range $(-0.000007: 0.000007)$, interval 0,1 \\
H4-ER144 & Intensitas Cahaya & $=\left(\$ B \$ 2 * \$ D \$ 2^{\wedge} 2 / 2^{*} \$ \mathrm{~B} \$ 6\right)^{\wedge} 2 *(2 * \mathrm{BESSELJ}(\$ \mathrm{~B} \$ 2$ \\
& & $\left.\left.* \$ \mathrm{D} \$ 2^{*} \mathrm{SQRT}\left(\$ \mathrm{G} 4{ }^{\wedge} 2+\mathrm{H} \$ 3^{\wedge} 2\right) ; \$ \mathrm{~A} \$ 2\right)\right) /\left(\left(\$ \mathrm{~B} \$ 2^{*} \$\right.\right.$ \\
& & $\left.\left.\mathrm{D} \$ 2^{*} \mathrm{SQRT}\left(\$ \mathrm{G} 4^{\wedge} 2+\mathrm{H} \$ 3^{\wedge} 2\right)\right) / \$ \mathrm{~B} \$ 6\right)^{\wedge} 2$ \\
\hline
\end{tabular}

\section{HASIL DAN PEMBAHASAN}

Pembelajaran fisika terbilang sulit jika dilakukan tanpa tatap muka. Beberapa kesulitan siswa maupun mahasiswa sudah banyak dijelaskan dalam penelitian terdahulu diantaranya kesulitan memahami suatu masalah, kurang memahami konsep yang digunakan pada soal (Pratama \& Sakdiyah, 2020). Sedangkan kesulitan dengan prosentase tertinggi adalah capaian yang membutuhkan percobaan secara langsung dalam proses pembelajaran (Winarti, 2021). Salah satu materi fisika yang membutuhkan percobaan secara langsung yaitu optika. Pembahasan materi optika dengan sub bab difraksi yaitu pada difraksi Fraunhofer dan difraksi Fresnel. Namun pada artikel ini hanya akan dijelaskan penggunaan simulasi pada difraksi Fraunhofer. 
Pada artikel ini menunjukkan salah satu solusi dalam pembelajaran dimasa pandemi. Pembelajaran jarak jauh menggunakan simulasi spreadsheet dan GNU Octave merupakan salah satu solusi pembelajaran dimasa pandemi COVID-19. Pembelajaran secara komputasi dengan melakukan analisis simulasi difraksi juga merupakan sebuah inovasi. Simulasi difraksi telah berhasil dibangun dalam paper ini menggunakan celah lingkaran (circular aperture) yang ditunjukkan pada Gambar 3. Difraksi Franhoufer merupakan difraksi yang terjadi apabila letak sumber cahaya, celah, dan layar pengamatan berada pada jarak yang jauh. Sehingga bentuk muka gelombang yang masuk ke celah berbentuk datar dan pola difraksi memiliki bentuk dan intensitas yang konstan.

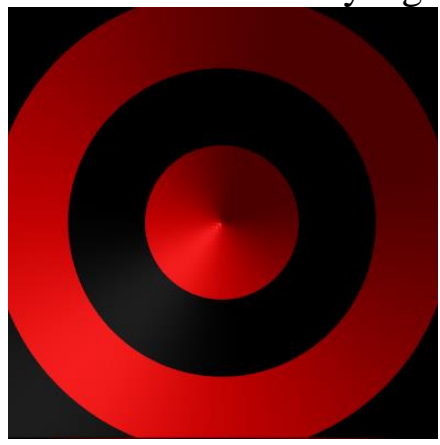

(a)

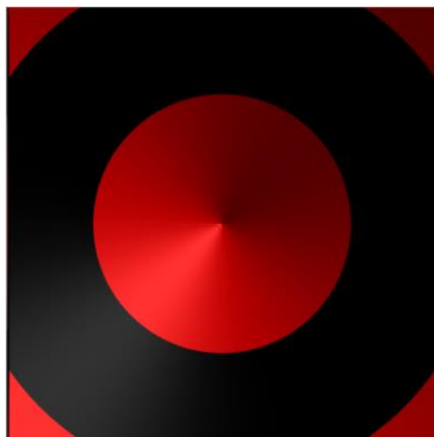

(c)

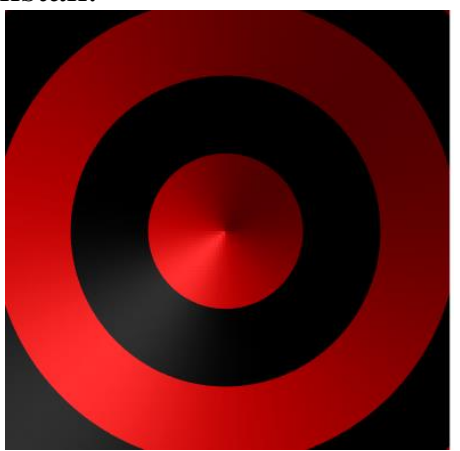

(b)

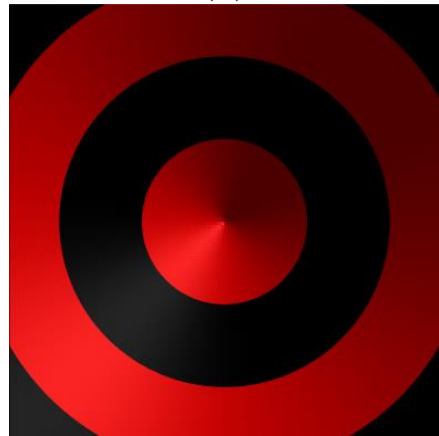

(d)

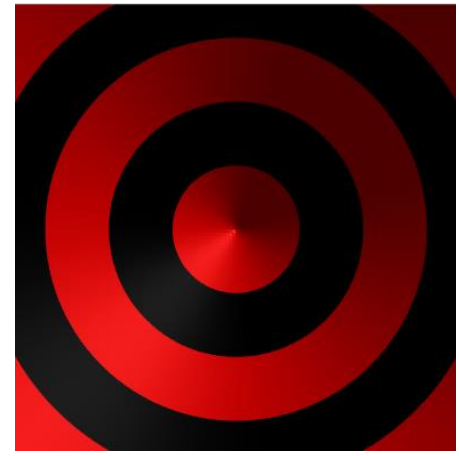

(e)

Gambar 3. Intensitas Cahaya Satu Bukaan Lingkaran dengan (a) panjang gelombang 400nm, (b) panjang gelombang 500nm, (c) panjang gelombang 600nm, (d) panjang gelombang 700nm, (e) panjang gelombang 800nm

Pada Gambar 3 menunjukkan intensitas cahaya dengan satu bukaan lingkaran dengan panjang gelombang 400nm hingga 900nm dengan nilai $k$ berkisar antara 0.015707963 hingga 0.006981317 dan nilai pajang fokus lensa $a$ sebesar 1. Simulasi yang dibuat juga menggunakan fungsi Bessel jenis pertama. Pola difraksi pada Gambar 3 menunjukkan panjang gelombang sumber cahaya, mempengaruhi pola difraksi. Sedangkan simulasi satu bukaan sejajar dengan lebar celah $0.15 \mathrm{~mm}$ menggunakan Software GNU Octave ditunjukkan pada Gambar 4. 


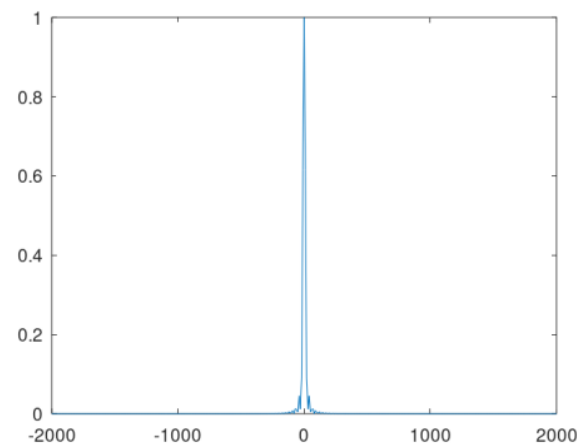

(a) $\lambda=400 \mathrm{~nm}$

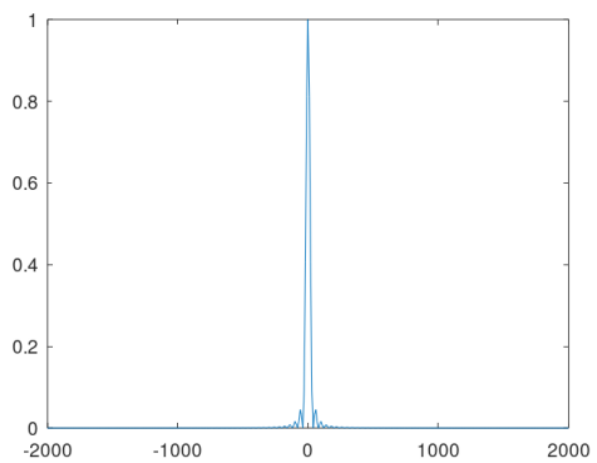

(c) $\lambda=600 \mathrm{~nm}$

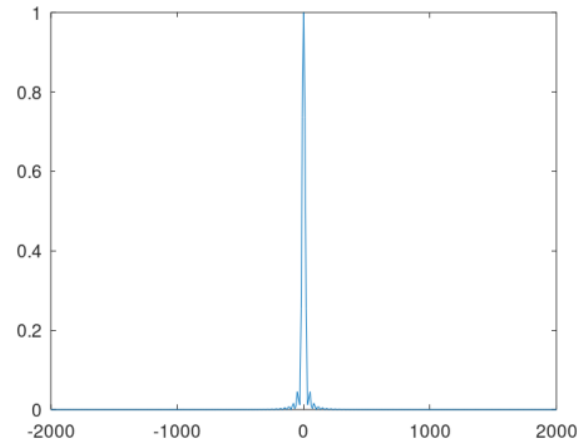

(b) $\lambda=500 \mathrm{~nm}$

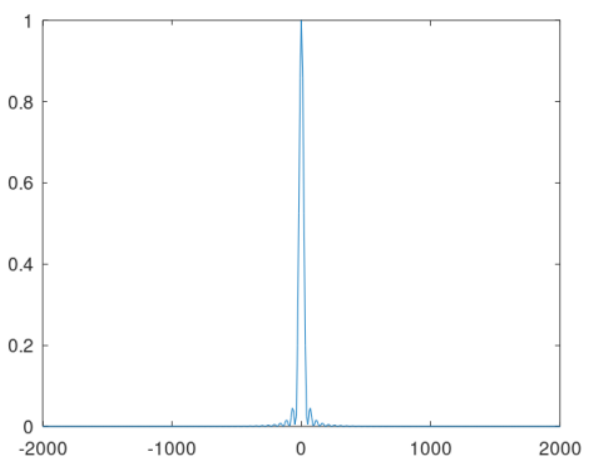

(d) $\lambda=700 \mathrm{~nm}$

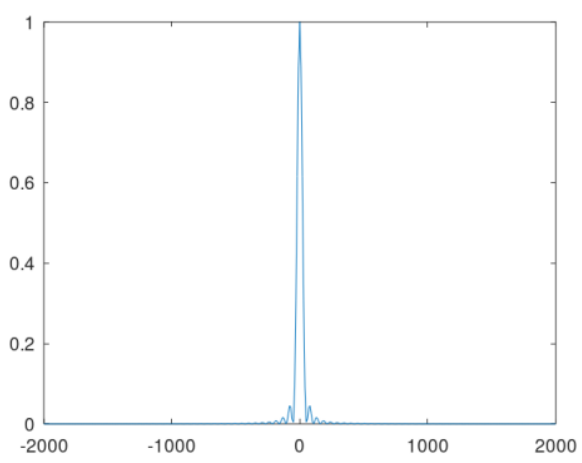

(e) $\lambda=800 \mathrm{~nm}$

Gambar 4. Simulasi GNU Octave satu bukaan sejajar (a) pajang gelombang $400 \mathrm{~nm}$, (b) panjang gelombang $500 \mathrm{~nm}$, (c) panjang gelombang $600 \mathrm{~nm}$, (d) panjang gelombang 700 $\mathrm{nm}$, (e) panjang gelombang $800 \mathrm{~nm}$.

Pada Gambar 4 menunjukkan bahwa panjang gelombang mempengaruhi pola difraksi. Semakin besar panjang gelombang maka pola difraksi semakin melebar. Sintak pemrograman pada GNU Octave ditunjukkan pada Gambar 5. 


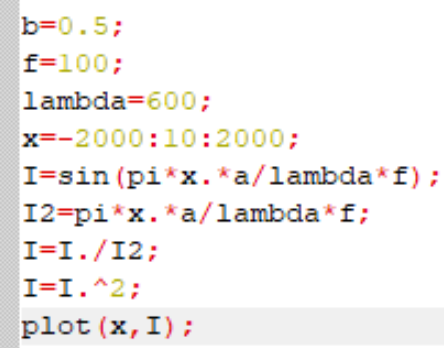

Gambar 5. Simulasi menggunakan GNU Octave pada satu bukaan sejajar.

Simulasi menggunakan GNU Octave dibuat seperti pada Gambar 5. Langkah pembuatan simulasi: pertama membuat variabel inputan yaitu $a$ dan $b$ radius lingkaran sebesar $0.15 \mathrm{~mm}$ dan $0.5 \mathrm{~mm}$, sedangkan $f$ fokus sebesar $100 \mathrm{~mm}$, dengan panjang gelombang $\lambda$ sebesar 600 $\mathrm{nm}$. Kemudian dimasukkan kedalam persamaan 2 untuk mendapatkan pola difraksi.

Simulasi yang sudah dibuat telah berhasil menunjukkan pola difraksi Fraunhofer celah lingkaran (circular aperture) berupa grafik 2 dimensi. Simulasi yang dibuat menampilkan pola difraksi dengan variasi panjang gelombang yang berbeda-beda (Zubair et al., 2019). Hasilnya menunjukkan kesamaan yaitu panjang gelombang menentukan pola cincin disekitar pusat lingkaran. Panjang gelombang dapat juga digunakan untuk mengukur frekuensi spektrum (Tipler \& Mosca, 2007). Hasil visualisasi juga memiliki kemiripan dengan hasil simulasi penelitian (Zubair et al., 2019). Hasil penelitiannya menunjukkan bahwa panjang gelombang hanya mempengaruhi distribusi intensitas pola difraksi, panjang gelombang yang besar akan menghasilkan distribusi intensitas difraksi yang lebih besar juga.

Simulasi difraksi Fraunhofer yang berbantuan Media Spreadsheet dan GNU Octave dapat digunakan sebagai salah satu alternatif pelaksanaan pembelajaran fisika yang lebih variatif. Mengingat pembelajaran fisika yang dilaksanakan selama pandemi COVID-19 sering kali hanya memfokuskan pada penugasan kepada mahasiswa (Azlan et al., 2020). Pendidik jarang yang memberikan perkuliahan atau pembelajaran kepada siswanya dengan berbagai alasan salah satunya mengenai keterbatasan perangkat pembelajaran jarak jauh. Melalui simulasi ini, mahasiswa dapat betambah paradigmanya mengenai konsep fisika yang diajarkan oleh pendidik kepada mereka (Hutchins et al., 2020). Mereka dapat menerapkan secara mandiri konsep fisika yang disampaikan oleh para pendidik melalui simulasi visual menggunakan media Spreadsheet dan GNU Octave. Kedua media tersebut merupakan beberapa alternatif media simulasi visual yang gratis sehingga dapat dengan mudah dioperasikan oleh mahasiswa (Vieira et al., 2019). Lebih lanjut, diharapkan dengan adanya variasi pembelajaran fisika selama pandemi COVID-19 yang mengintegrasikan simulasi difraksi Fraunhofer yang berbantuan Media Spreadsheet dan GNU Octave dapat meningkatkan motivasi belajar fisika dan hasil belajar mahasiswa.

\section{KESIMPULAN}

Paper ini telah berhasil membuat simulasi difraksi Fraunhofer menggunakan spreadsheet maupun GNU Octave. Simulasi difraksi Fraunhofer menggunakan bentuk celah simetris yaitu celah lingkaran (circular aperture). Simulasi pada pola difraksi dan kurva yang telah dibuat menunjukkan bahwa panjang gelombang mempengaruhi pola difraksi. Pembelajaran jarak jauh ini memungkinkan mahasiswa untuk mengembangkan keterampilan komputasi dan pemahaman konseptual difraksi Fraunhofer.

\section{SARAN}

Diperlukan pembanding antara simulasi yang dibuat dengan percobaan secara langsung untuk membuktikan hasil yang didapatkan. 


\section{DAFTAR PUSTAKA}

Azlan, C. A., Wong, J. H. D., Tan, L. K., Muhammad Shahrun, M. S. N., Ung, N. M., Pallath, V., Tan, C. P. L., Yeong, C. H., \& Ng, K. H. (2020). Teaching and learning of postgraduate medical physics using Internet-based e-learning during the COVID-19 pandemic - A case study from Malaysia. Physica Medica, 80(September), 10-16. https://doi.org/10.1016/j.ejmp.2020.10.002

Hati, H., \& Sapiruddin, S. (2020). Penerapan Modeling Instruction Dan Simulasi PhET Dalam Meningkatkan Kemampuan Menganalisis. Kappa Journal, 4(1), 76-84. https://doi.org/10.29408/kpj.v4i1.1820

Herraprastanti, E. ., \& Jatmiko, S. (2019). J URNAL T eknik M esin. 12(2), 38-45.

Hutchins, N. M., Biswas, G., Maróti, M., Lédeczi, Á., Grover, S., Wolf, R., Blair, K. P., Chin, D., Conlin, L., Basu, S., \& McElhaney, K. (2020). C2STEM: a System for Synergistic Learning of Physics and Computational Thinking. Journal of Science Education and Technology, 29(1), 83-100. https://doi.org/10.1007/s10956-019-09804-9

Nurdianto, N., Safiuddin, L. O., \& Eso, R. (2020). Simulasi Persamaan Difraksi Fraunhofer pada Celah Lingkaran dengan Menggunakan Visual Basic for Application (VBA) Spreadsheets Excel. Jurnal Penelitian Pendidikan Fisika, 5(3), 215. https://doi.org/10.36709/jipfi.v5i3.13812

Pradana, S. D. S., Parno, P., \& Handayanto, S. K. (2017). Pengembangan tes kemampuan berpikir kritis pada materi Optik Geometri untuk mahasiswa Fisika. Jurnal Penelitian Dan Evaluasi Pendidikan, 21(1), 51-64. https://doi.org/10.21831/pep.v21i1.13139

Pratama, N. D. ., \& Sakdiyah, H. (2020). Analisis Kesulitan Siswa Dalam Memecahkan Masalah Fisika Berbentuk Grafik. UPEJ Unnes Physics Education Journal, 5(3), 32-39. https://doi.org/10.15294/upej.v5i3.13729

Pratidhina, E., Dwandaru, W. S. B., \& Kuswanto, H. (2020). Exploring Fraunhofer diffraction through Tracker and spreadsheet: An alternative lab activity for distance learning. Revista Mexicana de Fisica E, 17(2), 285-290. https://doi.org/10.31349/REVMEXFISE.17.285

Valenko, T., \& Klanšek, U. (2017). An integration of spreadsheet and project management software for cost optimal time scheduling in construction. Organization, Technology and Management in Construction: An International Journal, 9(1), 1627-1637. https://doi.org/10.1515/otmcj-2016-0028

Vieira, A. L., Nespeca, M. G., Pavini, W. D., Ferreira, E. C., \& Gomes Neto, J. A. (2019). A user-friendly excel spreadsheet for dealing with spectroscopic and chromatographic data. Chemometrics and Intelligent Laboratory Systems, 194, 103816. https://doi.org/10.1016/j.chemolab.2019.103816

Winarti, P. (2021). Analisis Kesulitan Belajar Mahasiswa dalam Perkuliahan Konsep Dasar IPA Fisika Secara Daring di Masa Pandemi Covid-19. Jurnal Komunikasi Pendidikan, 5(1), 93. https://doi.org/10.32585/jkp.v5i1.1076

Yanuarief, C. (2016). Simulasi pola difraksi Fraunhofer untuk celah lingkaran dengan 
modifikasi fungsi Bessel. Integrated Lab Journal, 4(2), 181-188.

Zhang, Z., Bai, H., Yang, G., Jiang, F., Ren, Y., Li, J., Yang, K., \& Yang, H. (2013). Computer simulation of Fraunhofer diffraction based on MATLAB. Optik, 124(20), 4449-4451. https://doi.org/10.1016/j.ijleo.2013.03.004

Zubair, A., Kahfi, A., \& Yanuarief, C. (2019). Variasi Panjang Gelombang Cahaya Pada Simulasi Pola Difraksi Fraunhofer Untuk Celah Lingkaran. November 2019, 102-111. 